\title{
СИБИРСКИЕ СКИФЫ ТАЕЖНОГО ПРИИРТЫШЬЯ
}

\author{
Захарова Светлана Сергеевна \\ магистрант
}

Научный руководитель: Сухарев Андрей Иванович доцент, кандидат педагогических наук заведующий кафедрой дизайна, монументального и декоративного искусства «Омский государственный педагогический университет» (ФГБОУ ВО «ОмГПУ»). Факультет искусств Кафедра Дизайна, монументального и декоративного искусства

Аннотация: Задача статьи - рассказать об искусстве Саргатских скифов и их особенностях. Кроме того, рассказать об истории и на примере авторской росписи показать изделие, украшение, применимое в современном интерьере.

Ключевые слова: Саргаты, скифы таежное прииртышье, авторская роспись.

\section{SIBERIAN SCYTHIANS OF THE TAIGA IRTYSH AREA}

\section{Zakharova Svetlana Sergeevna Sukharev Andrey Ivanovich}

\footnotetext{
Abstract: The goal of the article is to tell about the art of the Sargat Scythians and their features. In addition, tell about the history and, using the example of the author's painting, show the product, the decoration that is applicable in the modern interior.

Key words: Sargats, Scythians taiga near-Irtysh, author's painting.

Цель работы - описать историю саргатской культуры и использовать авторскую роспись виде примера.

Методы и объекты исследования: Саргатская культура южного прииртышья их история и особенности изделий и орнаментов
} 
Результаты: рассказ о саргатской культуре скифов, орнаментика и значение, применение в современных изделиях.

\section{Введение:}

В эпоху повышенного информационного шума и ярких рекламных лозунгов крайне важны представления: о Родине о Сибири; ценности места, где человек появился на свет; о хрупкости и самобытности окружающего мира; глубине культурных традиций - зачастую они не формируются, незаслуженно позабыты и требуют к себе внимания.

Статья посвящена аутентичным, уникальным Сибирским особенностям региона, звериному стилю, на основах раскопок «Сибирских пирамид». В наши дни аутентичная культурная среда нашего города не отличается от других городов России. С помощью уникального наследия «Саргатской культуры»(VII век до н. эры), найденной при раскопках курганов в Омской области, мы создадим несколько объектов с использованием символов и орнаментики сибирских скифов, которая незаслуженно забыта.

На примере авторской росписи мы рассмотрим орнаментику саргатцев и узнаем об истории зарождения культуры.

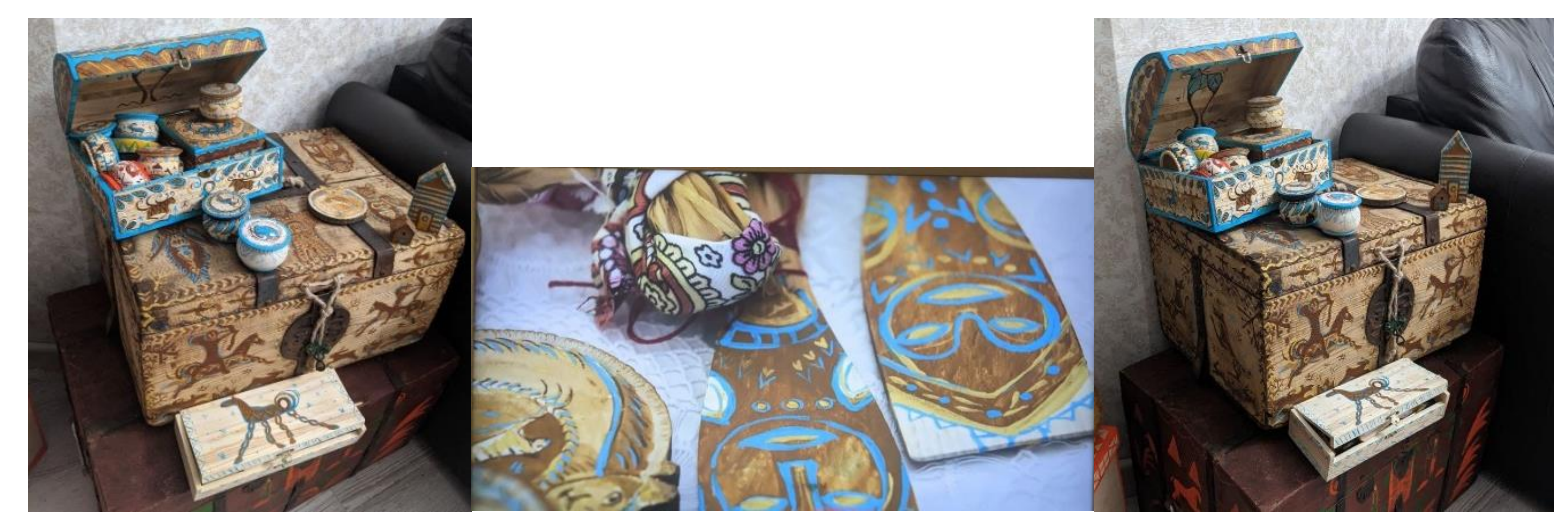

Рис. 1. Изделия из дерева, расписанные с использованием орнаментики Саргатцев

- Уникальная роспись таежного прииртышья нацелена на возрождение и популяризациию искусства Прииртышья «Саргатская - Кулайская культура».

- Культура саргатов очень интересна и сохраняя ее в мотивах и изделиях мы не потеряем самоидентичности. В век тотальной цифровизации ненужно забывать о своих корнях, чтоб не потерять сибирскую индивидуальность. 
- На примере росписи (рис.1) деревянных заготовок создадим маленькие произведения, которые помогут украсить наш дом и помогут познакомиться и изучить сибирских скифов.

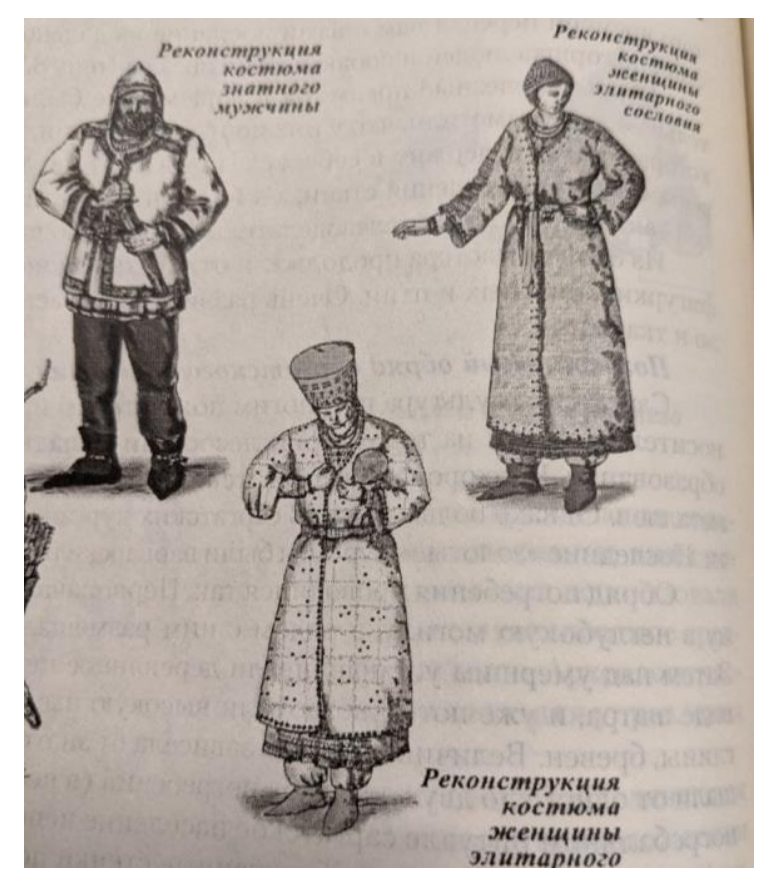

Рис. 2. Образы Саргатцев, воссозданные костюмы на основе найденных при раскопках

Культура «Саргатов» - археологическая культура, действующая с VII-VI веков до н. э. по III-V века н. э. в лесостепи Зауралья и Западной Сибири, вдоль рек - Иртыши, Ииима, Тобола, по течению Оми и Исети. Северные артефакты саргатской культуры найдень на просторах Тобольска. На юге ареал культуры совпадает с южной границей лесостепи. В восточных предгорьях Урала на западе и в Барабинской лесостепи на востоке также были найдены саргатские поселения и могильники". Проживали на данной местности не менее 1000 лет.

По всей лесостепи Западной Сибири, от Урала до Барабы, в VI веке до н. э. - IV веке н. э. заселяли племена саргацев (рис.2) (название получили по материалам раскопок в селе Саргатка Омской области). Были владельцами земель Иртыша до самого устья Тобола, а на юге их владения простирались до жаркой выжженной степи. Параллельно с культурой саргатцев существовала культура кулайцев, проживающих и занимающих территорию противоположную берега иртыша. Две культуры существовали, договариваясь между 
собой, периодически между ними возникали стычки, одна культура скифов влияла на другую.

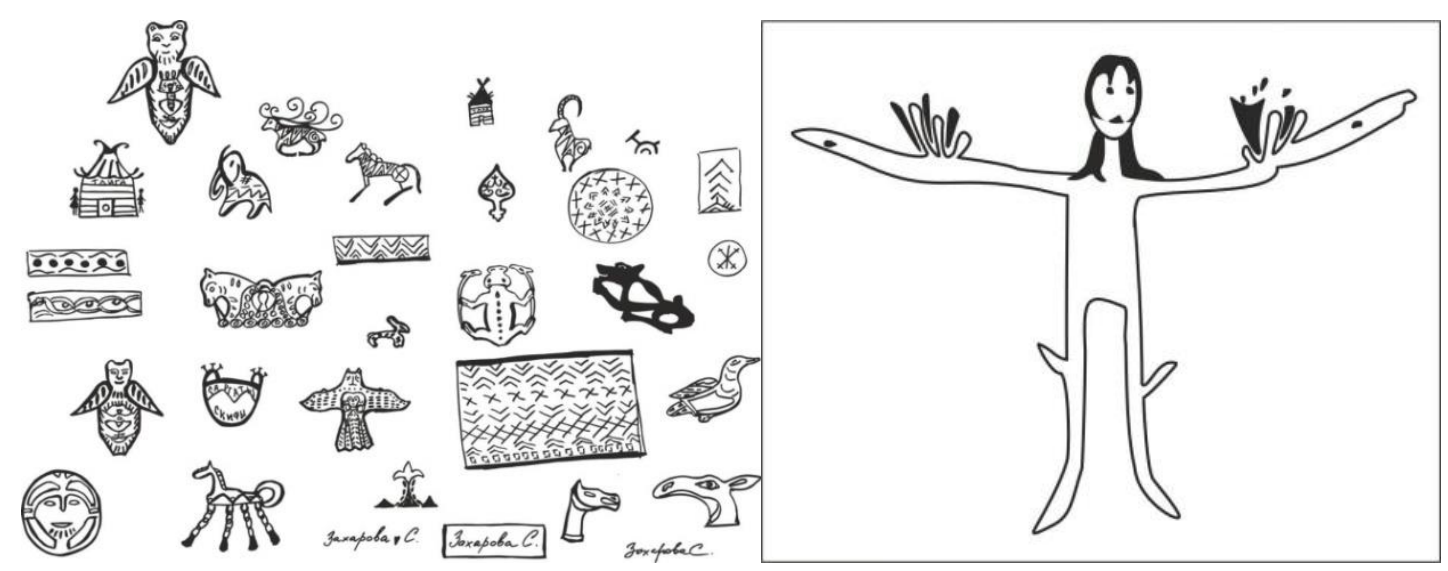

Рис. 3. Основные символы и элементы саргатской и кулайской культуры

Саргатская культура существовала на протяжении скифского и гунносарматского времени (VI в. до н. э. - V в. н. э.). Развивалась в несколько этапов. Памятники Саргатской культуры представлены поселениями, городищами, курганами. Жилища как однокамерные, так и многокамерные. Площадь их существенно варьирует по величине. Деревянные сооружения полуземлянки, котлован которых слегка углублен в почву. В центре жились располагался очаг, он служил обогревом. Исследованы и обширные наземные жилища - балаганы. Укрепления многообразны, городища саргатцев состояли из наружного рва и внутреннего вала и бревенчатых стен. Захоронения совершались, как правило, под курганскими насыпями. Могильник «сибирская пирамида» состоял из нескольких сооружений, которые возводились из пластов дерна. Диаметр их изменялся от нескольких метров до нескольких десятков метров. Наибольшие по высоте конструкции достигали 2-5 метров и более. Для Саргатской культуры характерно наличие элитных погребений с чрезвычайно богатым инвентарем из драгоценных металлов. В период освоения земель сибирских, сибирские пирамиды были разграблены бугровщиками. Саргатской культуры изготавливался по канонам сначала скифского, а затем гунно-сарматского времени. Вооружение: желез, мечи, бронзовые, железные и костяные наконечники стрел, остатки доспехов, атрибуты конской упряжи. Широк спектр орудий труда. Многочисленны украшения как из драгоценных и цветных металлов, ткачество особо развито и много изделий из стекла и камня. Посуда весьма разнообразна по форме и 
орнаментации. Это горшки, кувшины, чаши, блюда и т. д. Орнаментом покрывалась верхушка изделия: ряды горизонтальной елочки, свисающие на тулово резные треугольники и т. д [1]

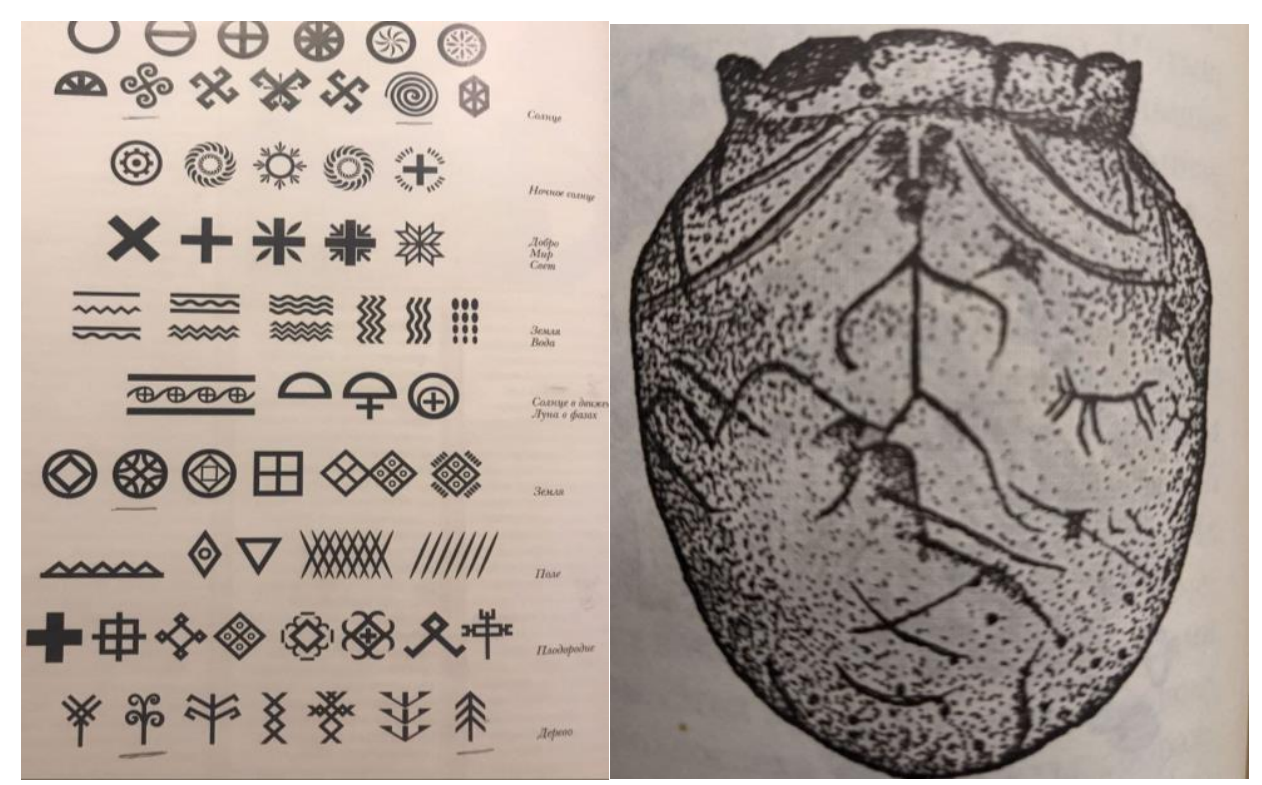

Рис. 4. Символы. Рис. 5. Керамический сосуд ранний

При распопах найдены кузницы и фигурки животных и птиц и отлитые наконечники стрел, множественные культовые чашы из бронзы и косторезные изделия. Саргатцы много охотились на мелкого и крупного зверя.

В Саргатской культуре широко развита керамика. На ней изображали людей, собак, горы и созвездия. Много найдено саргатских сосудов: формовка начиналась с горловины, а приостренное или плоское днище вкладывалось в уже готовую емкость; верхнюю часть начинали формировать с плечиков, затем наращивали горловину, которая могла состоять из одной-двух лент и примазывалась к плечику изнутри; Другой вид техники в саргатском гончарстве отражают сосуды, сделанные из одного куска глины. Саргатская керамика поселенческих и погребальных комплексов формовалась жгутовым или ленточным способом. Процедура нанесения орнамента осуществлялась в резной технике и в технике вдавления. Единичны жемчужины и наколы, нанесенные заостренной палочкой Часто орнамент наносился до обработки поверхности Об этом свидетельствует его «затертость» и наличие на нем зубчатых следов орудия обработки поверхности вдавлений. Орнамены мы видим на изделиях керамики и бронзовых изделиях.

Изделия из дерева не сохранились. 


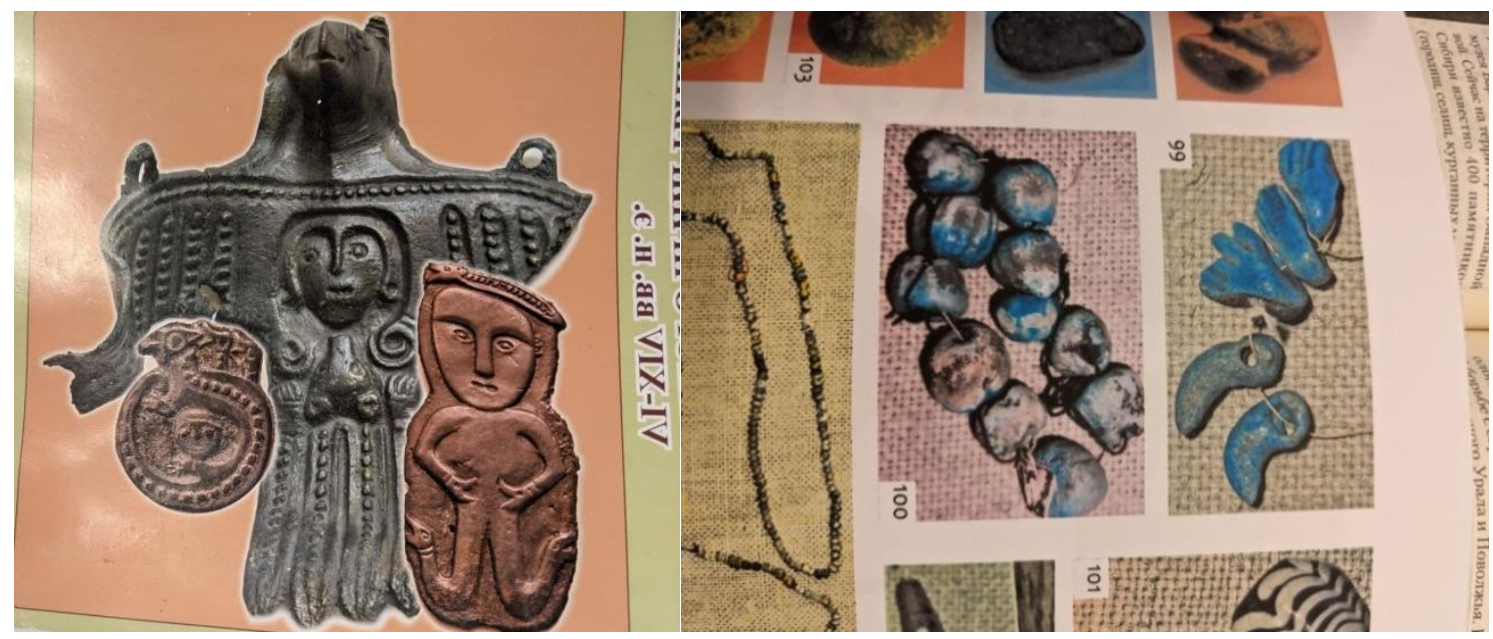

Рис. 6. Фигуркы из бронзы. Рис. 7. Украшения из лазурита и керамики

Важное место в обрядах и религиозных верованиях занимал огонь. выполнял охранительные и очистительные функции. В саргатской культуре существовал культ почитания коня, образ коня как тотемного животного воплощали в фигурках из глины, камня и бронзы. Главное занятие населения это производящее хозяйство. Позже в культуре потчевашского общества распространено почитание медведя.

- что медведь родоначальник всех людей, так же почитали филина, орла и лося, найдены фигурки в кургане окунево3, муромцевском районе.

- орел символ солнца и бессмертия соединял небесные и водные миры, а филин проводник по другим мирам.

- Лось помощник, проводник дух леса.

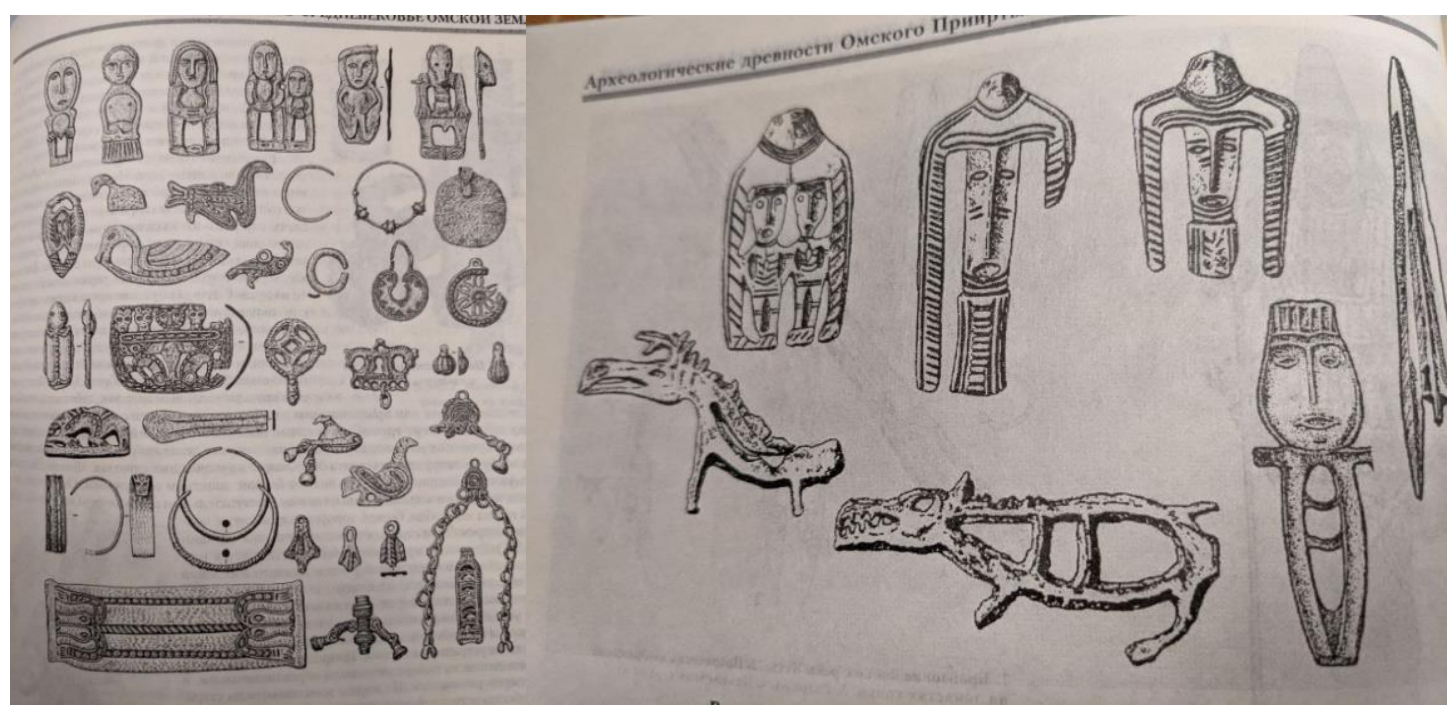

Рис. 8. Мурлинский клад, сокровища саргатцев, звериный стиль 
- Изображение елочек символизирует лесостепь, тайгу.

Воплощали в фигурки животный мир тайги «звериный стиль»: гуси, утки, глухари, тетерева ,совы, ушастые филины, лоси, лошади, медведь с лапами.

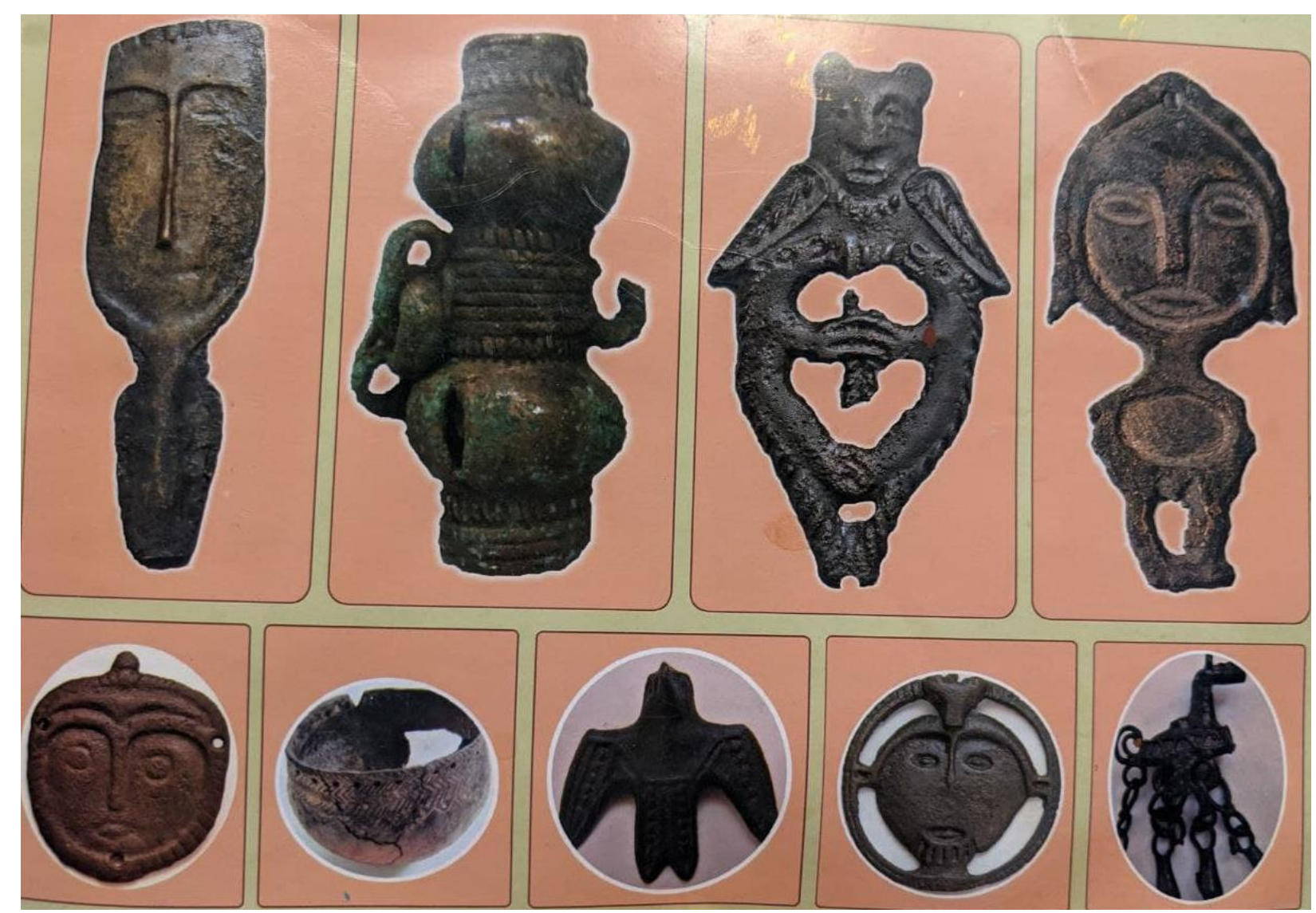

\section{Рис. 9. Бронзовые фигурки образы животных и людей}

- Изображение людей защитника рода.

Саргатская культура существовала в симбиозе с другими соседними культурами, и происходил обмен, снаряжались караваны и с пушниной, костью мамонтами, товарами, керамика бронза, животные. И часто в обиход попадали предметы из других культур. Если предметы попадали извне, они гармонично встраивались в систему ритуалов. 


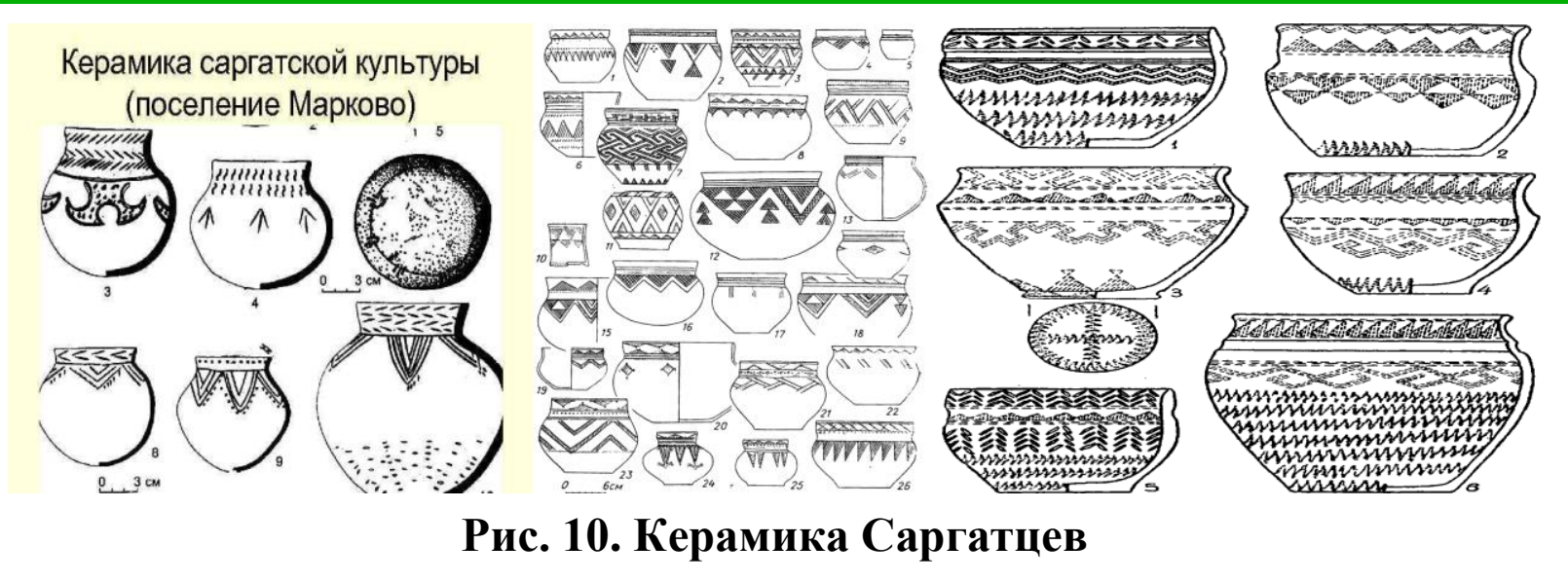

\section{Пример применения орнамента}

Для примера применения орнаментики Саргатцев выбрана авторская техника росписи «Таежного прииртышья». Дерево живой материал и поэтому роспись красками темпера выбрана не случайно, именно по этому материалу.

За основу 3 цвета краски

- Коричневая, охра - символ береговой глины.

- Бирюзово-голубая - это камень лазурит, встречающийся при раскопках в нашей местности

- И бронза - как символ железного века.

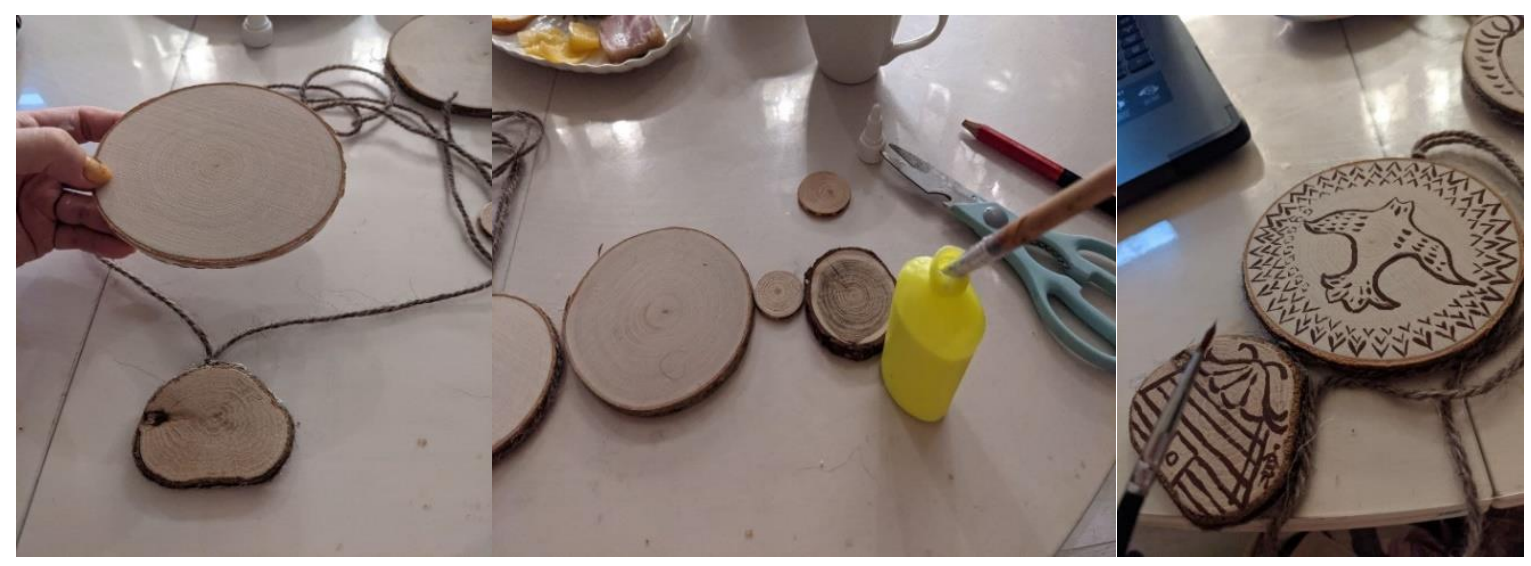

Рис. 11. Выбранные материалы и этап росписи

Композиция на украшениях строится по кругу, как бы символизирует солнце. Треугольники и чёрточки напоминают густую лесостепь и стихию. 


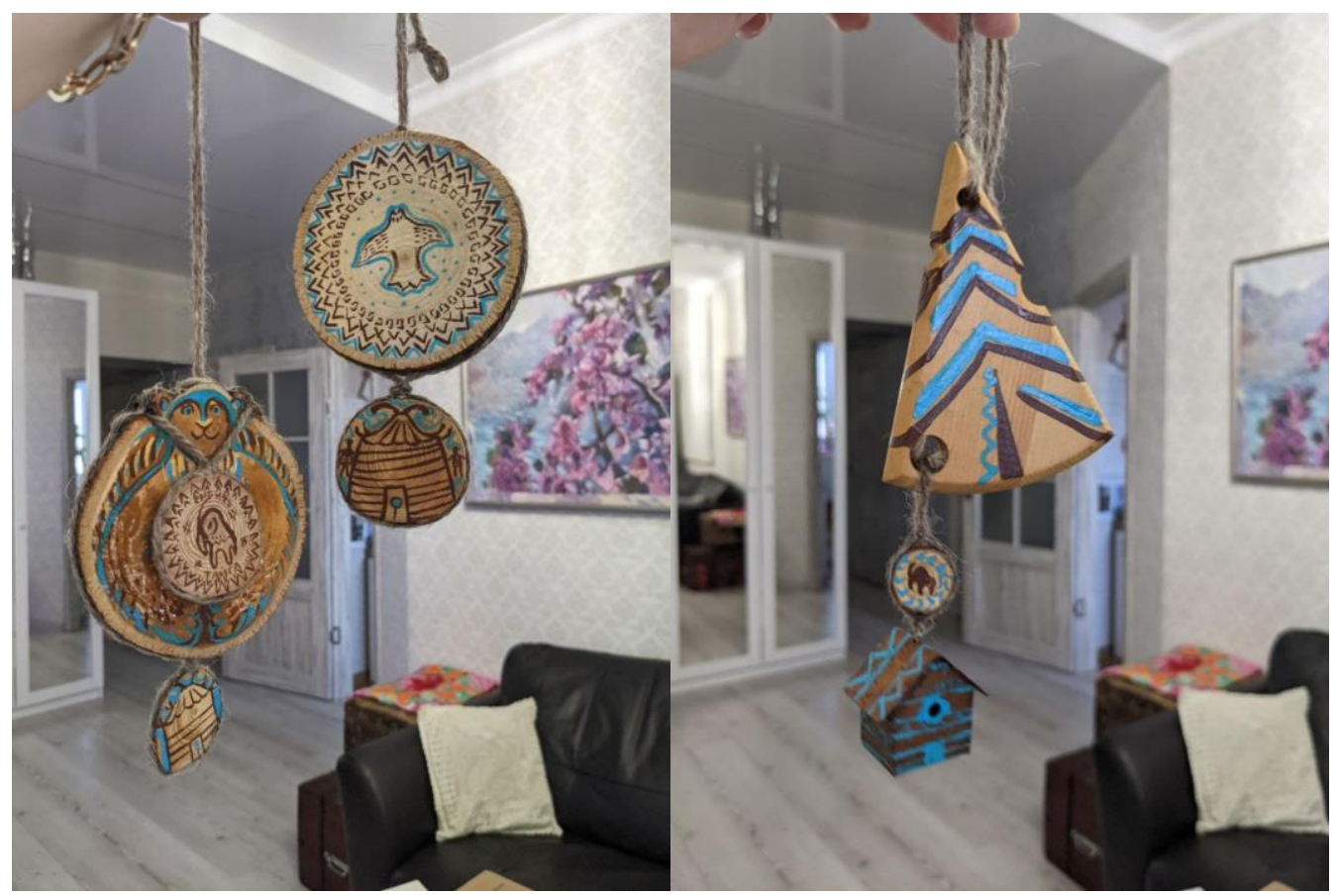

Рис. 12. Примеры готовых украшений

На предварительном этапе шлифовка и приклеивание шерстяной нити по периметру Кисти 0 и спил дерева сосны и березы - деревья, растущие в сибирском округе. Изделие шлифуется наждачной бумагой. На палитре выдавливаем нужную краску начинаем с коричневого, наносим как в традиции росписи легким касанием кисти, элементы елочки и стихии. Далее на крупные формы центральной композиции бирюзовой краской. На последнем этапе лакируем. Изделие готово можно оформлять новогодний интерьер.

Вывод:

Прикладное искусство скифов богато образами и сюжетами, которые несут глубокий смысл, создаваемые предметы и образы живые, способные воздействовать на человека. Очень важно изучать и сохранять традиции культуры своего региона и демонстрировать, а также находить место применения в современном мире. Именно в знаниях и сохранениях культурных традиций заключается богатство земли Российской и очень важно не растерять и сохранить эти знания для наших будущих потомков. 


\section{Список литературы}

1. Прикладное искусство южно-таежного прииртышья 6-14 вв.н.э,|Б.Ю.Коников, альбом, 84 с. ил.Омск 2020

2. Омского прошлое прииртышья \, П.П.Вибе, С.С. Тихонов, А.В. Матвеев, А.С.Авербух, Ю.В.Трофимов, 148 с.,ил, Омск 2005

3. Русский народный орнамент.І В.И. Ивановская - 208 с. ил., издательство В. Шевчук 2010. 